\title{
Influence of roughage in the rations of early weaned lambs
}

\begin{abstract}
The aim of this study was to assess the effect of exclusion of roughage from the ration of early weaned lambs. The experiment was carried out with 30 lambs from the Blackhead Pleven sheep breed weaning at 19.6days of age with an weight of $9.3 \mathrm{~kg}$ and divided in two groups. The lambs deprived of roughage intake by $26.8 \%$ more wheat grain, which is a prerequisite for a smaller expense of protein $4.6 \%$ and higher energy expenditure by $7.3 \%$ per $\mathrm{kg}$ gain. Average daily gain of lambs deprived of roughage was $2.9 \%$ less than lambs who received alfalfa hay $(\mathrm{P}>0.05)$. Lambs deprived of roughage have a higher carcas syield $(\mathrm{P}<0.05)$ and they accumulate by $9.2 \%$ more separable internal fat, which influenced the higher fatness, compared with lambs who received alfalfa hay. Insignificance was detected in the chemical composition of meat and weight of internal organs between the two groups of lambs.
\end{abstract}

Keywords: lambs, roughage, ration, average daily gain, alfalfa hay
Volume 2 Issue 4 - 2015

\author{
Miroslav Simeonov,' Krum Nedelkov, ${ }^{2}$ \\ Nikolai Todorov \\ 'Department of Preservation, quality evaluation and utilization \\ of forage crops, Research Institute of Forage Crops, Bulgaria \\ ${ }^{2}$ Department of Livestock, Trakia University, Bulgaria \\ ${ }^{3}$ Department Morphology, Physiology and Animal Nutrition, \\ Trakia University, Bulgaria
}

\begin{abstract}
Correspondence: Miroslav Simeonov, Department of Preservation, quality evaluation and utilization of forage crops, Research Institute of Forge Crops, Pleven 5800, Bulgaria, Tel +359878 632 I56, Fax +3596480588। Email msimeonov78@abv.bg
\end{abstract}

Received: June 22, 2015 | Published: July 14, 2015

\section{Introduction}

On the Balkan Peninsula, sheep lamb during the winter months, which necessitate to house and feed the lambs in indoor production systems. The proper nutrition of growing lambs is essential for their growth and development during the winter month, and the aim is attaining the desired live weight over a short time period with low feed expenditure. During that period, the major part of the ration of ruminants consists of roughages, ${ }^{1}$ hence the roughage costs are the primary part of expenses at farms. Blackwood, ${ }^{2}$ describes roughages as feeds with low energy and protein value, high crude fiber content and depending on their chemical composition; they are poorly utilized by animals. The amount and quality of roughage in dairy cows rations according to Allen ${ }^{3}$ determines the milk yield of cows. Roughages are bulky and therefore difficult to be transported, and related costs make the produce more expensive. At fattening, the dietary energy and protein levels provided by concentrate feeds are the important.

The type of roughage and their inclusion in the rations of lambs are disputable. According to Askar et al., ${ }^{4}$ the presence of roughage in lambs' diet reduces concentrate intake and digestibility, this suppressing the performance of animals. Concentrate feed consumption could be influenced by the type of the roughage, ${ }^{5}$ as well as by the physical shape of concentrates. ${ }^{6}$ Feeding early weaned lambs with concentrate only results in higher weight gain and more efficient feed conversion, without digestive disorders as reported by Tait et al., ${ }^{7}$ and lower feed expenditure per $1 \mathrm{~kg}$ weight gain as outlined by Ørskov et al. ${ }^{8}$ According to Heinruchs, ${ }^{9}$ Jones $^{10}$ do not recommend the use of hay in the diet of calves due to the lower energy content compared to concentrate feed, which disagrees with data reported by Anderson, ${ }^{11}$ Waterman. ${ }^{12}$ The aim of this study was to assess the effect of exclusion of roughage from the ration of early weaned lambs.

\section{Materials and methods}

\section{Experimental lambs, weaning and rearing}

The experiment was performed in 2011 with 30 lambs form the Blackhead Pleven Sheep breed, divided in two groups in order to evaluate the effect of excluding roughage from their diet. Sheep with lambs born within 4days were selected from the two main herds of the Institute of Forage Crops, Pleven. After 5days of age, lambs had free access to creep. ${ }^{13}$ The weaning was gradual, by restricting suckling time to $10-15 \mathrm{~min}$ with gradually increasing the periods between suckling episodes. ${ }^{14}$ The restricted suckling began at a live weight of $8.9 \mathrm{~kg}$ and 14.6days of age and ended with lambs at 19.6days of age with average weight of $9.3 \mathrm{~kg}$.

At weaning, the lambs were divided in two groups with equal birth date and lambing type, live weight at birth and weaning each group consisted of 7 female and 8 male lambs. The two groups were fed the same ration consisting of pelleted protein concentrate (PPC), and wheat $(1: 1)$. The used PPC was the same for both groups and contained $20.5 \%$ soybean meal and $50 \%$ sunflower meal. The aforementioned feeds were provided in such amounts that there always were leftovers from both feed types in the next morning. The lambs from the second group were deprived by roughage (alfalfa hay).

In both groups of lambs PPC and wheat, was put in separate feeder trays so that the animals could choose. The chemical composition of used feeds determined by the standard methods ${ }^{15}$ is presented in Table 1. During the entire experimental period, the lambs had a permanent access to cold pure tap water with temperature of about $20^{\circ} \mathrm{C}$, whose amount and leftovers were measured on a daily basis. The offered feeds and their residues were weighed at 6.00AM every morning to determine feed intake. Following this feeding regimen, every lamb included in the experiment was reared up to $26-27 \mathrm{~kg}$ live weight, determined after 12 hour water deprivation and 24 hour fasting.

The live weight was measured with electronic scales at birth, at weaning (start of the experiment) and at 7day intervals until the end of the trial. Lambs were weighed in the morning before the new feed was offered, and at the end of the trial were weighed after 12 hour water deprivation and 24 hour fasting.

\section{Slaughter analysis and sampling}

At the end of the experiment, slaughter analysis of 5 male lambs 
from each group was performed after attaining a live weight of $26 \mathrm{~kg}$ The internal organs were separated and weighed, and samples from kidney fat tissue were obtained for determination of fatty acid content. Carcasses were graded as per the (S) EUROP system within 1 hour after slaughter, ${ }^{16}$ then were cut in halves and stored at $4^{\circ} \mathrm{C}$ for $24 \mathrm{~h}$ as described by Zahariev. ${ }^{17}$ From each carcass half, samples from m. Longissimus dorsi were carefully collected for determination of meat chemical composition after storage of samples at $-20^{\circ} \mathrm{C}$.

Table I Composition and nutritive value of feedstuffs ( $g . \mathrm{kg}^{-1}$ at natural moisture)

\begin{tabular}{|c|c|c|c|c|c|c|c|c|c|c|c|}
\hline \multirow{2}{*}{ Feed stuffs } & \multicolumn{11}{|c|}{ Chemical composition } \\
\hline & DM & $\mathbf{C P}$ & EE & CF & NFF & Ash & FUG* & PDI* & BPR* & $\mathbf{C a}$ & $\mathbf{P}$ \\
\hline PPC $\boldsymbol{\Delta}$ & 87.59 & 314 & 20 & 99.8 & 468 & 98.2 & I.II & 148.2 & 98.4 & 12.5 & 10.03 \\
\hline Wheat & 85.98 & 132.5 & 17.6 & 36.3 & 793 & 20.6 & 1.39 & 98.8 & -16.8 & 0.51 & 3.91 \\
\hline Alfalfa Hay & 87.01 & 147.2 & 18.9 & 304.6 & 451.2 & 78.1 & 0.65 & 73 & 46 & 11.3 & 1.59 \\
\hline
\end{tabular}

$\Delta$ Pelleted protein concentrate; *Date are according Todorov et al.,30 corrected for moisture content Feed units for growth (IFUG=6 MJ net energy growth) for crude fiber, PDI and BPR for crude protein content

DM, dry matter; CP, crude protein; EE, ether extract; CF, crude fiber; Ash, crude ash; NFF, nitrogen-free extract; FUG, feed units for growth; PDI, protein truly digestible in small intestine; $B P R$, balance of protein in the rumen; $\mathrm{Ca}$, calcium; $\mathrm{P}$, phosphorus

\section{Analytical methods}

The contents of water, dry matter, protein, fat and ash contents of Muscle Longissimus dorsi was determined according to per Association of Official Analytical Chemists. ${ }^{15}$

\section{Economical evaluation}

The price of the bought feed was according to the sum for Pelleted protein concentrate (PPC). The price of the feed produced in the Institute of Forage Crops, Pleven (wheat and alfalfa hay) was according to the prices in the country for the respective period, taken from the Newsletter of the System foragrarian market economy.

\section{Statistical analysis}

The statistical analysis of data was done with Statistica for Windows software. ${ }^{18}$ The groups were compared using t-test, as differences at $\mathrm{P}<0.05$ were considered significant.

\section{Results}

\section{Feed consumption}

Intake of feed and dry matter in the lambs fed alfalfa hay was by $7 \%$ higher than those in the other group (Table 2). The lack of alfalfa hay in lambs from the second group was the reason for the higher intake of concentrate throughout the experimental period (Figure 1), which has led for the higher expense of concentrated feed and feed units for growth per $\mathrm{kg}$ gain (by $16.3 \%$, Table 2).

Intake of the energy was by $4.5 \%$ higher in lambs deprived from roughage compared to lambs from the first group (Table 2). Intake of the protein in lambs from the second group was by $7.4 \%$ lower vs. form the first group, but this did not influence the protein truly digestible in intestines: the between-group difference was under 3\% (Table 2). The lack of alfalfa hay was responsible for the lower crude fiber $(53.7 \mathrm{~g} /$ day) and calcium intake $(4.794 \mathrm{~g} /$ day $)$, as compared to lambs from the first group (Table 2).

\section{Growth of lambs}

According to the results, the lambs from the first group fed alfalfa hay had a higher average daily gain, compared to animals deprived of roughage, but difference of $2.9 \%$ was statistically insignificant
( $P>0.05$, Table 3).During the first 3 post weaning weeks (up to 21 days of age), the growth of lambs was almost similar, and thereafter lambs fed alfalfa hay grew faster than those deprived from roughage ( $\mathrm{P}>0.05$, Figure 2).

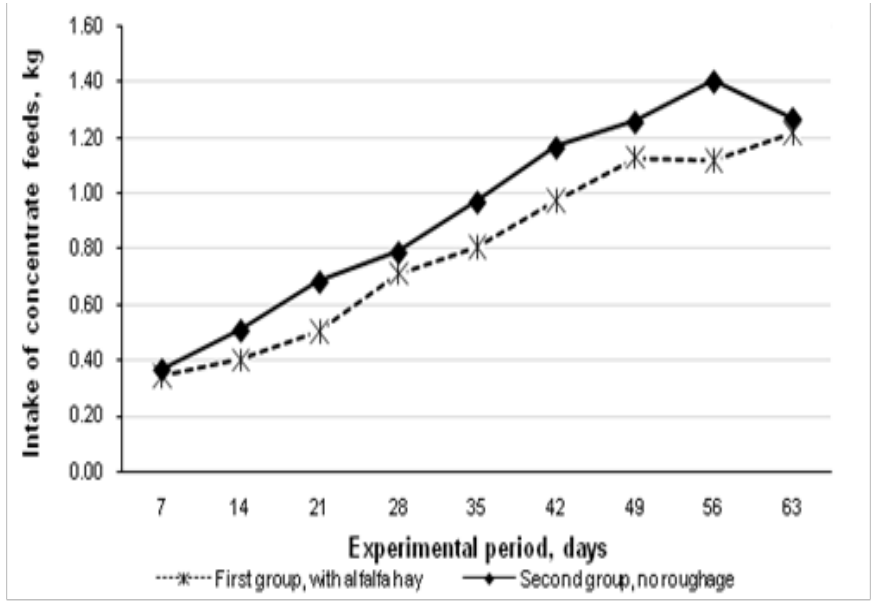

Figure I Dynamics of concentrate intake during experiment period.

\section{Slaughter analysis}

The lambs deprived of roughage had a statistically significantly higher carcass yield compared to those from the first group $(\mathrm{P}<0.05$, Table 3). Separable internal fat amount was by $9.2 \%$ higher in lambs deprived from roughage which was manifested by higher carcass adiposity $(\mathrm{P}<0.05$, Table 3$)$. The chemical analysis of Muscle Logissimus dorsi did not differ considerable between the groups (Table 4). The protein content was higher in the meat of lambs deprived from roughage whereas the fat content-in lambs fed alfalfa hay $(\mathrm{P}>0.05)$.

The used feeding schedules did not have a significant effect on the weight of internal organs (Table 5). According to the results, lambs fed alfalfa hay had a higher weight of small intestine and stomachs $(0.830$ and $0.813 \mathrm{~g}$ respectively)than lambs deprived from roughage $(0.742$ and $0.767 \mathrm{~g}$ ), but the differences were not statistically significant. The difference in feed costs per lamb and per kg weight gain in both groups was under $2 \%$, but per $\mathrm{kg}$ carcass the costs were by $5 \%$ lower in the group deprived from roughage (Table 6). 


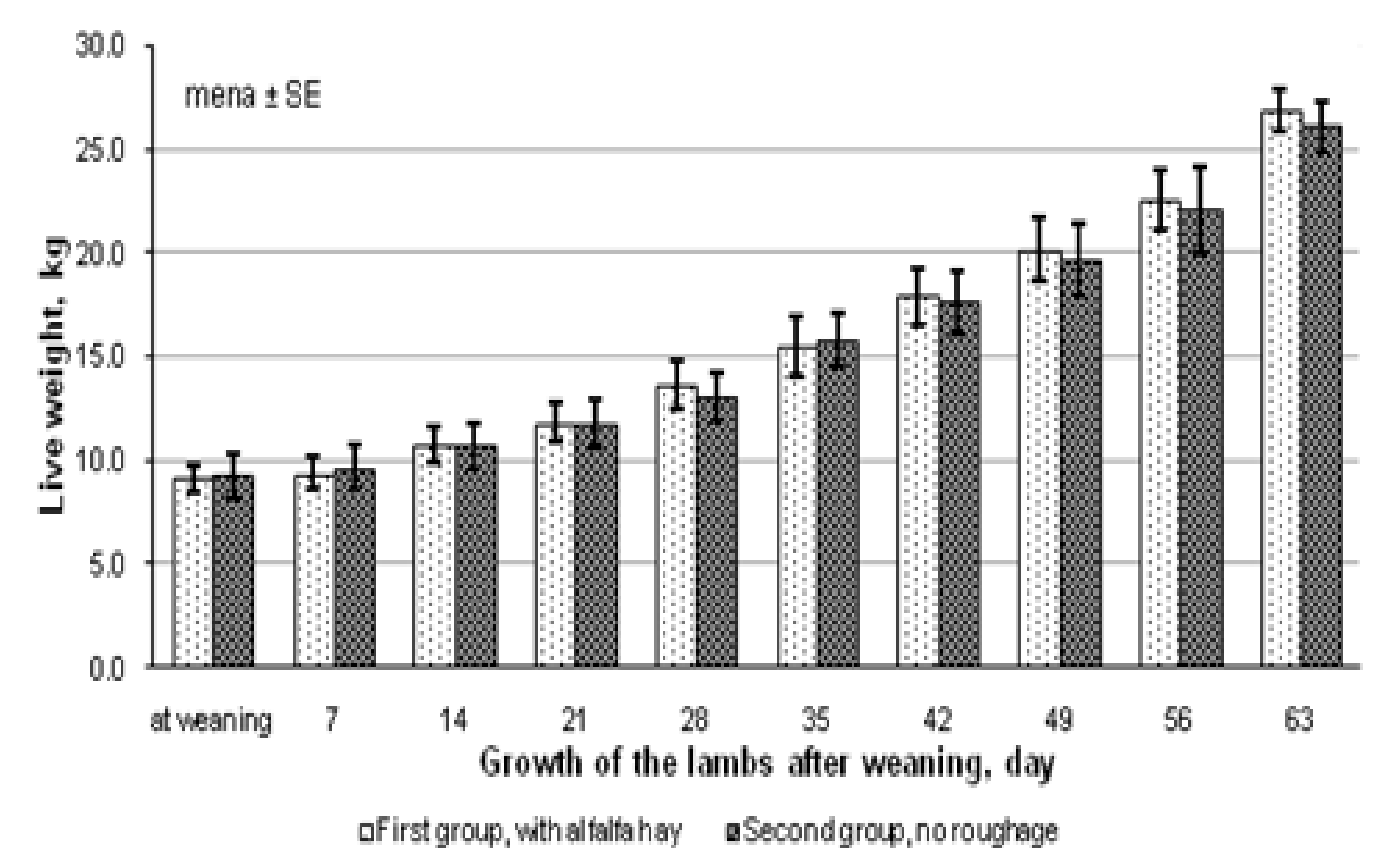

Figure 2 Changes in the live weight during the trial.

Table 2 Expenditure of feed for experiment period

\begin{tabular}{lll}
\hline Indicators & $\begin{array}{l}\text { I Group, } \\
\text { With alfalfa hay }\end{array}$ & $\begin{array}{l}\mathbf{2} \text { Group, } \\
\text { no roughage }\end{array}$ \\
\hline Intake of feed by animal, kg/day & & \\
Alfalfa Hay & 0.208 & 0 \\
Pelleted Protein Concentrate & 0.43 I & 0.416 \\
Wheat & 0.407 & 0.556 \\
All Feed & 1.046 & 0.972 \\
All Dry Matter & 0.908 & 0.842 \\
Intake of Ash,g/day & 66.95 & 52.3 \\
Intake of Drinking water,g/day & 2.997 & 3.314 \\
Water,kg/Dry Matter & 3.301 & 3.936 \\
Intake of energy and nutrients by animal per day & & \\
Feed Units Growth (FUG)* & 1.179 & 1.235 \\
Crude Protein,g & 191.7 & 177.6 \\
Crude Protein, \% form Dry Matter & 21.1 & 21.1 \\
Protein truly Digestible in Small Intestine (PDI), g* & 103.8 & 101.2 \\
Balance of Protein in the Rumen (BPR), g* & 39.6 & 27.8 \\
Crude Fiber,g & 105.6 & 53.7 \\
Calcium,g & 6.949 & 4.794 \\
Phosphorus,g & 5.448 & 5.52 \\
Expense of feed, energy and nutrients per kg gain & & 3.1 \\
Dry Matter,kg & 3.266 & 3.574 \\
Concentrate Feed,kg & 3.014 & 657.8 \\
Feed Units for Growth (FUG)* & 4.241 & \\
Protein truly Digestible in Small Intestine (PDI), g* & 373.4 & \\
Crude Protein,g & 689.6 & \\
\hline & & 3.6 \\
\hline
\end{tabular}

*Date are according Todorov et al., ${ }^{30}$ corrected for moisture content Feed units for growth (IFUG=6MJ net energy growth) for crude fiber, PDI and BPR for crude protein content 
Table 3 Growth of the lambs and slaughter data

\begin{tabular}{|c|c|c|c|}
\hline Indicators & $\begin{array}{l}\text { I Group, } \\
\text { with Alfalfa hay }\end{array}$ & $\begin{array}{l}2 \text { Group, } \\
\text { no Roughage }\end{array}$ & Significance \\
\hline LW at Birth,kg & $4.434 \pm 0.164$ & $4.694 \pm 0.54 I$ & ns \\
\hline LW at Weaning kg & $9.183 \pm 0.639$ & $9.352 \pm 1.093$ & ns \\
\hline LW at the end of the Experiment,kg & $26.943 \pm 1.008$ & $26.167 \pm 1.169$ & ns \\
\hline - ADG (from weaning to the end of the Experiment,kg & $0.278 \pm 0.018$ & $0.270 \pm 0.024$ & ns \\
\hline \multicolumn{4}{|l|}{ Age, day } \\
\hline - at Weaning & $19.3 \pm 0.714$ & $20.0 \pm 1.125$ & ns \\
\hline - at the end of the Experiment & $83.3 \pm 3.435$ & $82.3 \pm 3.703$ & ns \\
\hline Experiment Period & $64.0 \pm 3.697$ & $62.3 \pm 4.302$ & ns \\
\hline \multicolumn{4}{|l|}{ Slaughter data } \\
\hline Pre-slaughter Weight,kg & $26.567 \pm 0.338$ & $26.433 \pm 0.233$ & ns \\
\hline Carcass Weight,kg & $12.330 \pm 0.286$ & $12.823 \pm 0.249$ & ns \\
\hline Carcass Yield,\% & 46.4 & 49.36 & $*$ \\
\hline Separable Internal Fat,kg & $0.475 \pm 0.099$ & $0.523 \pm 0.062$ & $*$ \\
\hline Fattens & 2.7 & 3 & ns \\
\hline
\end{tabular}

*P<0.05;ADG, average daily gain; ns, non significant

Table 4 Chemical composition of Muscle Logissimus dorsi

\begin{tabular}{llll}
\hline components\% & $\begin{array}{l}\text { I Group, } \\
\text { with } \\
\text { alfalfa hay }\end{array}$ & $\begin{array}{l}\text { 2 Group, } \\
\text { no roughage }\end{array}$ & Significance \\
\hline Water & 74.55 & 74.53 & $\mathrm{~ns}$ \\
Dry Matter & 25.45 & 25.47 & $\mathrm{~ns}$ \\
Protein & 19.82 & 20.727 & $\mathrm{~ns}$ \\
Fat & 4.52 & 3.693 & $\mathrm{~ns}$ \\
Ash & $1.1 \mathrm{I}$ & 1.05 & $\mathrm{~ns}$ \\
\hline
\end{tabular}

Ns, non-significant

Table 5 Weight of internal organs

\begin{tabular}{llll}
$\begin{array}{l}\text { Organs Weight, } \\
\text { kg }\end{array}$ & $\begin{array}{l}\text { I Group, } \\
\text { with Alfalfa } \\
\text { Hay }\end{array}$ & $\begin{array}{l}\text { 2 Group, } \\
\text { no Roughage }\end{array}$ & Significance \\
\hline Heart & 0.133 & 0.137 & ns \\
Lung & 0.483 & 0.58 & ns \\
Liver & 0.63 & 0.633 & ns \\
Spleen & 0.067 & 0.067 & ns \\
Small Intestine & 0.83 & 0.742 & ns \\
L.S.I.,cm* & 2602.7 & 2705.7 & ns \\
Large intestine & 0.34 & 0.347 & ns \\
Stomachs & 0.813 & 0.767 & ns \\
Diaphragm & 0.133 & 0.113 & ns \\
Kidney & 0.123 & 0.137 & ns \\
\hline
\end{tabular}

* LSI, length of small intestine; ns, non-significant
Table 6 Price of feed stuffs consumed by one lamb per day of experiment

\begin{tabular}{llll}
\hline Feed/Indicators & $\begin{array}{l}\text { Perce/ton, } \\
\text { euro }\end{array}$ & $\begin{array}{l}\text { I Group, } \\
\text { with alfalfa } \\
\text { hay }\end{array}$ & $\begin{array}{l}\text { 2 Group, } \\
\text { no } \\
\text { roughage }\end{array}$ \\
\hline $\begin{array}{l}\text { Alfalfa Hay } \\
\begin{array}{l}\text { Pelleted Protein } \\
\text { Concentrate }\end{array}\end{array}$ & 127.82 & 0.027 & - \\
$\begin{array}{l}\text { Wheat } \\
\text { Total per Lamb }\end{array}$ & 200.43 & 0.082 & 0.142 \\
Per I kg Gain & & 0.256 & 0.1111 \\
Per kg Carcass & & 0.921 & 0.253 \\
\hline
\end{tabular}

\section{Discussion}

The deprivation of lambs from roughage led to statistically significantly higher carcass yields $(\mathrm{P}<0.05)$ and significantly had more amount of separable fat in comparison to animals receiving alfalfa hay (Table 3). Loerch ${ }^{27}$ and Haddad $^{24}$ also reported higher slaughter yields in goat kids and lambs fed a minimum amount of roughage, which has influenced the lower feed intake per $1 \mathrm{~kg}$ weight gain. When roughage was included in the ration of lambs, their meat would meet the requirements of consumers (less amount of fat, lower carcass adiposity) which makes it economically rewarding..$^{28}$ In this study, the results did not exhibit statistically significant differences in the chemical composition of meat between the two groups of lambs (Table 4). The intensive feeding with concentrate results in deposition of more fat and this makes the carcass unacceptable for consumers. ${ }^{29,30}$ This is not supported by the present study data both with respect to the amount of separable fat (Table 3 ) and the fat content of Muscle Logissimus dorsi (Table 4), probably due to the type of the used grain feed. In a previous study of ours, the feeding of early weaned lambs with corn grain has led in insignificantly higher carcass adiposity and fat content of Muscle Logissimus dorsi. ${ }^{21}$ Wheat 
contains $96 \%$ of the net energy of corn grain and is distinguished with higher crude protein content, thus being an appropriate feed for ruminants, ${ }^{31}$ associated to lower costs in the intensive rearing of lambs. ${ }^{32}$ The dietary roughage level in the view of Karim ${ }^{33}$ does not influence the chemical composition of meat.

The lower level of roughage in the diet of lambs according to Kumari et al., ${ }^{19}$ led to higher feed expenditure per $1 \mathrm{~kg}$ weight gain, probably because of the high cost of grain feeds in Ethiopia that makes them economically inefficient. In our study, the difference between the groups was under $2 \%$ in favour of lambs fed alfalfa hay. The feed expenditure per $1 \mathrm{~kg}$ carcass was by $5 \%$ lower in roughage-deprived lambs (Table 6). Jabbar \& Anjum ${ }^{34}$ reported that the lower dietary roughage level was related to lower feed expenditure per $1 \mathrm{~kg}$ weight gain, supported also by the investigation of $\mathrm{Haddad}^{24}$ in goat kids.

\section{Conclusion}

The deprivation of lambs from alfalfa hay until attainment of live weight of $26-27 \mathrm{~kg}$ did not have a considerable effect on the performance of animals and feed conversion. Deprived of roughage, lambs consumed by $26.8 \%$ more wheat grain, a prerequisite for lower protein expenditure (by 4.6\%) and higher energy expenditure (by $7.3 \%)$ per $1 \mathrm{~kg}$ gain. Expense of feed per $\mathrm{kg}$ carcass was $5 \%$ lower for lambs deprived of roughage.

\section{Acknowledgements}

None.

\section{Conflict of interest}

Author declares that there is no conflict of interest.

\section{References}

1. Chenost M. Optimizing the use of poor quality roughages through treatments and supplementation in warm climate countries with particular emphasis on urea treatment. Tropical Feeds and Feeding systems. 2001;71-92.

2. Blackwood I. Alternative roughage feeds. Prime Facts. 2006. p. 1-2.

3. Allen M. Relationship between fermentation acid production in the rumen and requirement for physically effective fiber. J Dairy Sci. 1997;80(7):1447-1462.

4. Askar A, Guada J, González J, et al. Diet selection by growing lambs offered whole barley and protein supplement, free choice: Effects on performance and digestion. Livestock Science. 2006;101(1-3):81-93.

5. Shain D, Stock R, Klopfenstein T, et al. The effect of forage source and particle size on finishing yearling steer performance and ruminal metabolism. J Anim Sci. 1999;77(5):1082-1092.

6. Weston R. Factors limiting the intake of feed by sheep. IX.*Furtherstudies of the roughage requirement of the ruminant lamb fed on concentrate diets based on wheat. Australian Journal of Agricultural Research. 1979;30(3):533-541.

7. Tait R, Bryant R. Influence of energy source and physical form of all concentrate rations on early weaned lambs. Can J Anim Sci. 1972;53:89-94.

8. Ørskov E, Fraser C, Gili J, et al. The effect in an intensive production system of type of sereal and time of weaning on the performance of lambs. Animal Prod. 1971;13:485-492.

9. Heinruchs A, Lesmeister K. Why you should hold off on feeding forage to calves. Hoard's Dairyman. 2000;145(16):638.
10. Jones C, Heinrichs J. Early weaning strategies; 2007.

11. Anderson K, Nagaraja T, Morrill J, et al. Ruminal microbial development in conventionally or early weaned calves. J Anim Sci. 1987;64(4):1215-1226.

12. Waterman D. Sources of nutrients for milk replacers and dry starter feeds and what factors impact quality. NRAES-175, Cooperative Extension. 2005;96-115.

13. Alcock D. Creep feeding lambs. Primefacts: profitableand sustainable primary industries. 2006;224:1-4.

14. Simeonov M. Effect of diferent methods of early weaning of lambs of dairy breeds and systems for feeding them. $\mathrm{PhD}$ thesis Institute of Forage Crops Pleven Bulgaria; 2013.

15. AOAC. Official Methods of analysis of AOAC international. 18th ed. Association of Official Analytical Chemists International. Gaithersburg, MD USA; 2007.

16. Raicheva E,Marinova P. Manual for Evaluation of live animals and Carcasses of Sheep. According to (S)EUROP System. Kostin brod(Bulgaria): Institute of Animal Sciences; 2002.

17. Zahariev Z, Pinkas A. Methods of Slaughter Analysis and Carcass Evaluation in Cattle. Sofia Bulgaria: NAPK; 1979.

18. Statistica. Statistica for Windows. Student Edition, Stat Soft Inc Tulsa OKUSA; 2006.

19. Kumari N, Reddy Y, Blummel M, et al. Growth performance and carcass characteristics of rowing ram lambs fed sweet sorghum bagasse-based complete rations varying in roughage-to-concentrate ratios. Trop Animal Health and Production. 2013;45(2):649-655.

20. Matejovsky K, Sanson D. Intake and digestion of low-, medium-, and high-quality grass hays by lambs receiving increasing levels of corn supplementation. J Anim Sci. 1995;73(7):2156-2163.

21. Simeonov M, Stoycheva I, Kirilov A. Feeding behaviour of lambs. Journal of Mountain Agriculture in the Balkans. 2012;15(3):508-517.

22. Bartle S, Preston R, Miller M. Dietary energy source and density: effects of roughage source, roughage equivalent tallow level, and steer type on feedlot performance and carcass characteristics. J Anim Sci. 1994;72(8):1943-1953.

23. Fimbres H, Hernández-Vidal G, Piocón-Rubio J, et al. Productive performance and carcass characteristics of lambs fed finishing ration containing various forage levels. Small Ruminant Research. 2002;43(3):283-288.

24. Haddad S. Effect of dietary forage: concentrate ratio on growth performance and carcass characteristics of growing Baladi kids. Small Ruminant Research. 2005;57(1):43-49.

25. Sebside A, Casey N, van Niekerk W, et al. Growth performance and carcass characteristics of three Ethiopian goat breeds fed grainless diets varying in concentrate to roughage ratios. South African J Anim Sci. 2007;37(4):221-232.

26. Bakshi M, Wadhwa M, Rana K, et al. Effect of roughage level on complete feed the rumen environment in crossbred cows. Indiana Journal of Animal Nutrition. 2004;21(3):158-163.

27. Loerch S. Effects of roughage additions and dietary switches on performance of feedlot cattle. Ohio Beef Cattle Research and industry Rep Anim Sci Dept Series. 1993;111:1-93.

28. Karim S, Patnayak B. Carcass characteristics of finisher lambs raised on varying levels of energy under heat exposure. Indian J Anim Sci. 1998;68(3):276-278.

29. Santra A, Karim S. Effect of dietary roughage and concentrate ratio on nutrient utilization and performance of ruminant animals. Animal Nutrition and Feed Technology. 2009;9(2):113-135. 
30. Todorov N, Krachunov I, Djuvinov D, et al. Handbook of Animal Feeding. Publ. Matcom. Sofia Bulgaria; 2007.

31. Sauvant D, Perez J, Tran G. Tables INRA-AFZ de composition et de valeur nutritive des matières premières destinées aux animauxd'élevage. 2ème ed. INRA Editions Varsailles; 2004. 302 p.

32. Tripathi M, Karim S, Chaturvedi H, et al. Nutrition value of animal feed grade wheat as replacement for maize in lamb feeding for mutton production. Journal of the Science of Food and Agriculture. 2007;87(13):2447-2455.
33. Karim S. Current status and future prospects of sheep for mutton production. In: Proceeding of IX Animal nutrition Research Workers Conference Dec 2-4 Hyberabad. India; 1999;85-98.

34. Jabbar M, Anjum M. Effect of diets with different forage to concentrate ratio for fattening of Lohi lambs. Pakistan Veterinary Journal. 2008;28(3):150-152. 